\title{
EL RUDO Y PENOSO MAGISTERIO DE UN INDIO: MAGISTERIUM, ASCETICISM AND MIMESIS IN EIGHTEENTH-CENTURY JESUIT HISTORIES OF LOWER CALIFORNIA
}

\author{
El rudo y penoso magisterio de un indio: Magisterium, ascetismo y mimesis en las historias \\ jesuitas de la Baja California durante el siglo XVIII
}

Bryan Green*

\begin{abstract}
This work makes a case for the study of ascetic practices in colonial Spanish-Americam society and historiography through an analysis of the eighteenth-century histories of the Jesuit missions in Lower California. The analysis will focus on the representation of the missionary's submission to the instruction of the inhabitants of the peninsula, described by Jesuit authors as "el rudo y penoso magisterio de un indio", in order to learn languages with little or no history of European contact. Jesuit narrative sought to reaffirm the mastery of Jesuit missionaries over their Amerindian catechumen by framing the missionary's experience within the Western ascetic tradition, thus uniting the Christian concept of magisterium with the ascetic ideal. Notwithstanding the Jesuits' performance of this tradition, these texts also reveal the unstable dialectic of colonial mimesis in which it is never clear who represents the legitimate reproduction and who represents the generate or parodic copy. Despite Jesuit authors' affirmations to the contrary, the missionary's performance of magisterium and the ascetic ideal ultimately depended on the colonizers' display of violence force, which assured the direction of acculturation and the reproduction of Castilian-Christian hegemony.
\end{abstract}

Keywords: Asceticism, colonial mimesis, hagiography, Lower California, Jesuits, magisterium, missionaries, New Spain.

\section{RESUMEN}

Este trabajo plantea la importancia del ascetismo para el entendimiento cabal de la historiografía y sociedad hispanoamericana a través del análisis de las historias de las misiones jesuitas de Baja california escritas por miembros de dicha orden religiosa durante el siglo dieciocho. El análisis se centrará en las representaciones de la sumisión de los misioneros a la instrucción de los indígenas de la península para aprender idiomas con poca o ninguna historia de contacto con la cultura europea, práctica que

\footnotetext{
* Instituto de Literatura y Ciencias del Lenguaje, Departamento de Literatura, Pontificia Universidad Católica de Valparaíso.
} Valparaíso, Chile. Correo electrónico: blgreen1@gmail.com

Received March, 8, 2013. Accepted August, 29, 2014. 
los autores jesuitas calificaron como "el rudo y penoso magisterio de un indio". Estas obras procuran reafirmar el dominio de los misioneros sobre sus catecúmenos indígenas a través de la narración de la experiencia del misionero dentro de la tradición occidental del ascetismo, lo que une el concepto cristiano de magisterium con el ideal ascético. No obstante la actualización de esta tradición por los misioneros jesuitas y sus cronistas, estos textos también demuestran la dialéctica inestable de la mimesis colonial donde a veces se confunden la reproducción legítima con la copia degenerado o paródica. A pesar de lo que afirman los autores jesuitas, la actualización del magisterium y el ideal ascético dependía en última instancia de la muestra de la violencia de parte de los colonizadores, la que aseguró el sentido de la aculturación y la reproducción de la hegemonía catellano-cristiana en la frontera misionera.

Palabras clave: Ascetismo, mimesis colonial, hagiografía, Baja California, Jesuitas, magisterium, misioneros, Nueva Espańa.

According to the twentieth-century Jesuit scholar Charles Polzer, the missionary enterprise on the northwest frontier of New Spain was guided by the principle of "magisterium," or the duty to teach and spread the message of Christianity as decreed in the Gospel according to Matthew, "Euntes ergo docete omnes gentes" ("Go forth and teach all nations"; 230). Just what was meant by the divine mandate "to teach all nations" was a matter of controversy from the early European polemics on the nature of the Amerindian, most notably in the "Controversia de Valladolid" in which Bartolomé de las Casas argued for teaching by the example of Christian charity against Juan Ginés de Sepúlveda, who insisted on the necessity of coercion as a prelude to the project of acculturation. As Polzer notes, this concept of magisterium, which implied a hierarchy between missionary and catechumen (or civilizing schoolmaster and barbarous pupil) was likewise complicated by the encounter at the edges of the Spanish empire between cultures with no common tradition. In the following I will examine the Jesuit missionary's enactment of magisterium in a series of eighteenthcentury histories of the order's apostolic campaign in Lower California, which was the order's last mission frontier in New Spain before their expulsion by order of Charles III in 1767. Specifically, I will focus on the representation of the missionary's submission to Amerindian linguistic instruction, a response to the contingencies of the mission frontier that overturned the hierarchy implicit in the concept of magisterium but also paradoxically became a trope of the Jesuits' ascetic ideal. ${ }^{1}$ Through the representation of scenes of contested pedagogical

\footnotetext{
1 I broadly define asceticism here as the willful practice of self-denial and discipline as a means to establishing spiritual and temporal order through the repetition of models of conduct preserved in a narrative tradition. The nature and development of asceticism in the West is, of course, one of the central problems of philosophical critique and sociological analysis of Christianity from Nietzsche's On the Genealogy of Morals up to the present. For Nietzsche, the priestly ascetic ideal, characterized by self-sacrifice and an irrational renunciation of pleasure as ultimate virtues, is not a model of good-will and charity but rather the expression of a will to power redirected against the self. As Nietzsche quips in one of the aphorisms from Human, all too Human with a play of words on the German adage "Eine Tugend aus der Not machen [To make a virtue of necessity]": "The ascetic makes a necessity of virtue." That is, the ascetic not only turns virtue into an external compulsion (as opposed to an inherent quality) but also converts a state of suffering and misery into the highest attainable virtue (60). Just as Nietzsche, Max Weber likewise viewed forms of asceticism in the West as the catalyst for the modern subject's self-understanding, although he shifted in focus from the concept of "resentment" to theodicy as central to religious ethics ("Social" 270). For Weber, theodicy, or the problem of the unequal distribution of fortune, was the central problem of all religions, but this dilemma was uniquely confronted in Christianity with the rejection of a debased and sinful world and the concomitant valuation of suffering as a sign of election; asceticism, therefore, became an increasingly rationalized set of techniques for mastering nature and oneself in order to assure salvation. As Jürgen Habermas has noted in his extensive examination of Weber's contribution to sociology and philosophy, this process of ethical
} 
authority (or magisterium), these texts were key to the reproduction of the missionary frontier as a symbolic space that not only provided a backdrop for the performance of the Jesuits missionary's ascetic ideal but also a model of conduct for Novo-Hispanic society at large. Nevertheless, these works also bear witness to what the anthropologist Michael Taussig terms the "space between" of colonial contact, a "space permeated by the colonial tension of mimesis and alterity, in which it is far from easy to say who is the imitator and who is imitated, which is copy and which is original" (78). In the performance of the magisterium and the ascetic ideal at the edges of Spanish America, the mimesis of Christian-Castilian hegemony often devolved into a destabilizing mimicry that could only be countered through the conjunction of violence and writing.

In his hagiographic narrative of the life and mission of Juan de Ugarte (1662-1730), one of the first Jesuit missionaries sent to Lower California, Juan Joseph de Villavicencio emphasizes that the exemplary Jesuit subject modeled his life after the Society's first martyr, Francisco Xavier, and "imitaba [...] al glorioso Apostol del Oriente en las correrías, y empresas apostólicas y procuraba serle semejante en las virtudes" (108-09). In Villavicencio’s Vida y virtudes de el venerable, y apostólico padre Juan de Ugarte (1752), as in all Jesuit narrative of the time, the missionary's experience on the colonial frontier ("las correrías y empresas apostólicas") was portrayed as a constant mortification and trial of the missionary's ascetic virtues, especially his patience, humility, poverty, obedience, and even chastity. In an extreme example of the ascetic's submission to textual models, Ugarte's hagiographer describes his subject's painful death alone in his solitary missionary outpost as the fulfillment of the missionary's desire to emulate the hagiographic narrative of the "glorioso Apostol del Oriente":"Quién dudara, que habiendo imitado el fervor, y zelo, los trabajos, sudores, correrías, y empresas Apostólicas de San Francisco Xavier, quiso también imitar la soledad, y desamparo con que murió en las isla desierta de Sanchón?” (133). While eighteenth-century Jesuit missionaries sought to imitate the immediate example of their illustrious confrères, whose lives were chronicled through the order's prolific production of hagiographic literature, both the missionary and his hagiographer recognized that this performance also echoed Saint Paul's Second Letter to the Corinthians, in which the proto-Apostle outlines the hardships of his apostolate, "on frequent journeys, in danger from rivers, danger from bandits, danger from my own people, danger from the Gentiles, danger in the city, danger in the wilderness, danger at sea, danger from false brothers and sisters" (2 Cor. 11.26).

As Gavin Flood argues, ascetic practices and their representations are performances of a tradition whereby the subject is linked to a community through the discipline of the

rationalization sets up the world as a trial of the subject's moral principles, but only some religious orientations "objectify" the world through an active asceticism directed towards the mastery of nature (Theory 1: 206-08). In his analysis of the place of the Jesuits in Weber's sociology, José Luis Villacañas argues that the Jesuits contribution to the ethical rationalization of a modern worldview was not through an economic ethic (as with the Protestant in Weber's thesis) but rather through the relation of self-discipline and the performance of a worldly vocation ad maijorem Dei gloriam, as instilled through St. Ignatious' Spiritual Exercises. St. Ignatius explicitly explains the dependence of the perfection of the self and the control of others' conduct in his "General Examen" from the Constituciones: "El fin de esta Compañía es no solamente atender a la perfección de las ánimas proprias con la gracia divina, mas con la misma intensamente procurar de ayudar a la salvación y la perfección de las de los prójimos" (Constituciones, 48). Pierre Hadot has demonstrated the the Jesuit's ascetic ideal, as embodied in the Spiritual Exercises, draws from the Greco-Roman tradition of askesis, understood as a form of philosophical meditation on death as a means of directing one's actions towards the realization of virtue $(82 ; 128)$. Recent studies of asceticism, such as those included in Vincent L. Wimbush and Richard Valantasis's Asceticism, have focused on the importance of ascetic practices in uniting communities through a lived religious tradition. On the relationship between narrative and asceticism, see the works by Geoffrey Galt-Harpham and Gavin Flood cited below. 
body and the production of language (15). The Christian ascetic tradition in particular, argues Flood, depends on an "entextualization of the body" wherein the ascetic subject's life is absorbed into collective memory through the production of texts and thus becomes a model for future performances of this tradition (166). Geoffrey Galt-Harpham likewise demonstrates that the ascetic ideal preserved in Christian hagiographic writing depends on successive interpretations of sacred writings through imitation; whereby the subject paradoxically exercises his will by submitting to textual models (42). Jesuit missionary narrative, such as Villavicencio's Vidas y virtudes, similarly depended on previous models of frontier asceticism which prefigure the subject's experiences and order his life through a familiar narrative. By portraying ascetic heroes that were shaped in Europe or the colonial center and then tested on the missionary frontier, these texts linked the Jesuit's mission on the colonial periphery to the ascetic ideal promoted in the pedagogical apparatus of the urban center, principally the Jesuit colleges and popular ministries. These texts reproduced the missionary frontier as the encounter with the savage, diabolic and perverse as a ground for the continued performance of self-discipline and discipline of the colonial other throughout Novo-Hispanic society. ${ }^{2}$

In the eighteenth-century Jesuit narratives written in New Spain and the metropole, the humbling and patient submission to the linguistic instruction of Amerindians whose languages were unknown to Europeans become a recognizable trope. At the start of their campaigns of conversion and acculturation, Jesuit missionaries were forced to renounce their authority and submit to the instruction of Amerindians in order to learn the languages of their would-be catechumens, a prerequisite to communication that, as Polzer notes, often revealed the mutual untranslatability of the two cultures. This inversion of roles threatened the hegemony of the colonizers' culture and was personally onerous to the missionaries. In his Noticia de la California y de su conquista temporal y spiritual hasta el tiempo presente (1757), the Spanish Jesuit historian Andrés Marcos Burriel describes Father Everardo Helen's (1679-1757) instruction in the Cochimí dialect of his catechumens as conducted under the "rudo, y penoso magisterio de un indio" (2:327-28). This already humbling submission to Amerindian mastery was frequently intensified by further submitting to the instruction of children, who were considered the most reliable

\footnotetext{
${ }^{2}$ Jesuit hagiography was directly connected to the proliferation of examinations of conscience and spiritual exercises in eighteenth-century New Spain that explicitly outline methods for inhabiting and emulating the sacred text in the layman's daily affairs. In Francisco Amadeo de Ormea's Compendio de la vida de nuestro Padre y Patriarca San Phelipe Neri en forma de meditación para el aparejo espiritual de la Fiesta del Santo (1714), a work originally written in Italian and translated to Spanish for use in New Spain, Saint Phillip of Neri's biography is divided into two weeks of meditations in which the reader is to reflect on episodes of the Saint's life. The meditations are meant to inculcate the virtues of the holy man (obedience, perseverance, humility, faith, rejection of the pursuit of worldly wealth as an end in itself) in the reader without actual reclusion to the monastery or flight to the desert. Citing Saint Ambrose, the text itself is offered as an ascetic exercise for those who must remain in the seculum: "teniendo la conversación en las ciudades, poseamos el desierto con la mente" (4rv). This distribution of the Saint's life along the calendar for the purpose of meditation and examination of conscience is likewise detailed in the Practica utilissima de los diez viernes a honor de S. Ignacio de Loyola, Patriarcha de la Compañia de Jesús (1749), a work originally written in Italian by Juan Santiago de Leti and translated to Spanish by the Criollo Jesuit Juan Francisco Lopez, a member of the Inquisition and a prolific author of Vidas y virtudes of the Society's Province of New Spain. Based on the techniques of the Spiritual Exercises, the readings from the life of Saint Ignatius are divided among 65 days (the ten Fridays of the title) leading up to the founder's feast. The logic of this structure is based on the life and death of Saint Ignatius, who lived 65 years and died on a Friday. The saint's life, structured by the text, becomes the matrix for the exercitant's own ascetic exercise, which in turn produces a text structuring the will of the reader: after reading each of the 65 chapters the reader is to write down his or her own reflections thus binding his actions to the greater glory of God.
} 
informants in their communities. The discourse of Jesuit historiography turns what was simply a response to the necessities of acculturation into an ascetic virtue: the subjection of the will in submitting to the instruction ("magisterio") of not only an Amerindian but an Amerindian child at that. Thus, the momentary subversion of the power structure in the contact zone paradoxically reaffirmed the hierarchy of master and pupil, of conqueror and conquered. This aspect of apostolic merit becomes a key element of Jesuit missionology and hagiography as both a tactic in the acculturating process and a topos of missionary narrative that reaffirms the Jesuit mastery; yet, the complex relation of magisterium, asceticism and mimesis in these works reveals the challenge of narrating this encounter as the realization of a self-evident and universal hierarchy of schoolmasters and pupils.

Throughout the Jesuit missions on the northwest frontier of New Spain the education of Amerindian children was the first concern of the missionaries (Spicer 296; del Río 177). Children offered less resistance to the teachings of the newcomers, had a greater capacity for assimilating the colonizers' language and culture, and could spend more time with the missionaries as they were not entirely incorporated into the economy of their communities or that of the mission. Most importantly, the monopolization of childhood education was an effective means of undermining the autochthonous cultures of the peninsula. What is less evident about this strategy is that it was more the result of necessity than a deliberate plan. Following a long-standing practice, Jesuit missionaries considered children more trustworthy informants than their elders and more likely to respect the authority of the missionaries, who seemed particularly sensitive to the slights received from Amerindian adults who they considered their intellectual inferiors. The case of Pedro Ugarte, like his older brother Juan a Jesuit missionary in California, who "hizo vivir en su casa [a dos niños], para que le fuessen primero Maestros de la Lengua, y despues le sirviessen de Catequistas," is indicative of the practice of using children as both native informants and as assistants in the acculturation of adults (Burriel 1:87-88). Burriel adds that Ugarte obliged these children to wear European clothes that they would leave hanging on a tree when they returned to their village and "de noche se vestían, para venir a ver al Padre, y dentro de su casilla dormían con el vestido puesto," thus demonstrating the power that the missionaries exercised over their young catechumens at the same time that these children were at least sometimes able to negotiate between two cultures (2: 88).

In the Empressas apostólicas de los padres misioneros de la Compañia de Jesús, de la Provincia de Nueva-España obradas en la conquista de Californias (1739), a vast manuscript chronicle of the Jesuit enterprise in Lower California, Miguel de Venegas presents an already recognizable scene in which Father Juan María Salvatierra (1648-1717), one the first Jesuits to establish permanent missions on the peninsula, humbles himself to the linguistic instruction of his child catechumens:

[...] a tales niños escoge el Señor por instrumentos para obras tan grandes: porque se saben humillar como niños, y dar a Dios la gloria de todo. Humillaronse los Padres en esto con hazerse discípulos en la lengua de los que havian de ser Maestros en la fe: y hallándose nińos con los niños, comunicaban continuamente con ellos, para aprender de su modo de hablar, no solo la substancia, y significación de las vozes, sino también el modo de pronunciarlas (107). 
Again, the Jesuit author measures his subject's ascetic virtue by the depth to which he allows himself to sink in order to minister to his flock, even becoming a disciple of the children of those he has come to convert. Venegas furthermore represents Salvatierra's submission as an enactment of the well-known words of Jesus from the Gospel According to Matthew: "you have hidden these things from the wise and the intelligent and have revealed to infants" (11.25). Thus, Jesuit discourse transformed the contentious and often violent dialectic that threatened to undermine their work into a narrative of the missionary's ascetic triumph over the will and dedication to a providential mission prefigured in Scripture.

The Jesuits were neither the first to employ this strategy of acculturation, nor were they the first to transform this strategic response to the contingency of the contact zone into an ascetic virtue. ${ }^{3}$ This particular form of apostolic merit arose from the conjuncture of the Franciscans' missionary enterprise in the recently conquered Tenochtitlan. In his Historia eclesiástica Indiana, Jerónimo de Mendieta describes the first Franciscan apostles' challenges in learning Nahuatl and the divinely inspired solution to their dilemma:

Hechas estas santas y humildes prevenciones, clamando a Dios continuamente, les acudió, como refugio que es de los atribulados y verdadero remedio en las tribulaciones, poniéndoles en su corazón, que con los niños que tenían por discípulos, se volviesen niños como ellos para participar de su lengua, y con ellos obrar la conversión de aquella gente pequeñuela, en sinceridad y simplicidad de niños. Y así fue que dejando a ratos la gravedad y austeridad de sus personas se ponían a jugar con ellos con pajuelas o pedrezuelas los ratillos que tenían de descanso, y esto hacían para quitarles el empacho de la comunicación y traían siempre papel y tinta en las manos y en oyendo el vocablo al indio lo escribían, y al propósito que lo dijo. A la tarde juntábanse los religiosos y comunicaban los unos a los otros sus escritos, y lo mejor que podían conformaban a aquellos vocablos el romance que les parecía más conveniente. Y acontecióles, que lo que hoy les parecía que habían entendido, mañana les parecía no así (qtd. in Cuevas 1: 182).

The Franciscans' distress at the impossibility of communicating with their catechumens leads to desperate entreaties to God, who plants within them the idea of submitting to the instruction of children. This divine solution not only allows them to begin the arduous process of learning Nahuatl, which continues to vex them, but more importantly restores their spiritual authority by demonstrating their willingness to renounce the gravity and austerity of their office and submit to the most simple and humble of their flock. While not the first to employ this discursive strategy in response to the contingency of the contact zone, the Jesuits transformed this particular practice of self-abnegation into a cornerstone of the order's ascetic ideal and worldwide apostolic mission. In the Jesuit narrative tradition that was central to the corporate identity and cohesion of the order, the mastery of non-European languages was evidence of the Jesuits' particular efficacy as missionaries as well as serving as a trial of their ascetic will to self-mastery.

\footnotetext{
${ }^{3}$ Mary Louise Pratt's well-known definition of "contact zone" aptly describes this reality of linguistic exchange and concomitant inversion of roles: "'contact zone' is an attempt to invoke the spatial and temporal copresence of subjects previously separated by geographic and historical disjunctures, and whose trajectories now intersect. By using the term 'contact,' I aim to foreground the interactive, improvisational dimensions of colonial encounters so easily ignored or suppressed by diffusionist accounts of conquest and domination. A 'contact' perspective emphasizes how subjects are constituted in and by their relations to each other. It treats the relations among colonizers and colonized, or travelers and 'travelees,' not in terms of separateness or apartheid, but in terms of copresence, interaction, interlocking understandings and practices, often within radically asymmetrical relations of power" (7).
} 
In José de Acosta's De procuranda indorum salute (1588), the foundational work on missionology for the Jesuits in Spanish America, this practical problem of the contact zone becomes the basis of a critique aimed at lax ministers as well as the foundation of the Jesuit missionary ideal on the colonial frontier. Referring to ministers who have not taken the trouble to learn Amerindian languages, Acosta asks “¿Pues qué hará el que no sabe lenguas ni tiene quien le traduzca sus palabras, obligado él mismo a ser bárbaro entre los bárbaros, sin saber hablar, y, por otra parte, sin poder callar?" (95). Acosta claims that the missionary who cannot communicate with his catechumens, although he bears a truth that he dare not keep quiet, is just as barbarous as the Amerindian. Nevertheless, this momentary loss of prestige is fundamental to the missionary's performance of the ascetic tradition: it becomes one more trial in which the he perfects his mastery and emulates the example of his forerunners. The Jesuit, who was the product of a rigorous and prolonged education in Classical languages and Christian theology, became a babbling pupil of a language spoken by people who were, in every way that was important to him, his inferiors. Yet this was one more instance that the Jesuit could, according to Acosta, "sintonizarse con los humildes," that is, follow the example of Christ through self-abnegation and prove his virtue by humbling himself before the most abased people he could find (1: 137). This perceived lack of power and submission to his inferiors became a trial in which the true missionary, that is the one who embodied the Jesuit ascetic ideal, proved his worth. By recourse to the ascetic ideal, the Jesuit thus restored the magisterial hierarchy that was overturned in the contact zone.

In her work on the Jesuit natural histories of the northwest frontier of New Spain, Ivonne Del Valle has described the mission as a space of language exchange in which the Jesuits' monological culture was threatened by the centrifugal forces of Amerindian resistance (77). Del Valle argues that the failure of the missionary led to a relegation of the traditional apostolic narrative (edifying letters, hagiographies, chronicles, etc.) with a consequent concentration in ethnography, botany and geography. According to Del Valle, this secular, scientific production is "la práctica occidental de autopreservación en condiciones de absoluta desventaja, un mecansimo aislado que permitía establecer con el medio ambiente una relación en la que el sujeto occidental conservaba cierto control" (189). While it is true that this scientific discourse was a means of reestablishing the Jesuits' contested authority on the mission frontier, her analysis does not take into account the fact that the Jesuits' hagiographic genres performed a similar function of justifying the colonial order by reaffirming the ascetic tradition in the midst of this order's decomposition on the frontier. Through the discourse of the Jesuits' ascetic ideal, in fact, these narratives converted the failure of the missionary enterprise (the missionaries' submission to Amerindian instruction, their inability to establish self-sustaining settlements, Amerindian rebellions, and ultimately martyrdom) into a triumph of the will that embodied the most hallowed virtues of the colonizers' culture. Thus, it was not the failure of the missionary to adapt to the cultures of the frontier that led to the abandonment of a hagiographic discourse in favor of the secular, scientific discourse of natural history. In fact, the former was an effective response to this failure, and in many aspects the Jesuits' scientific writings were a further application of this ascetic ideal.

While recognizing that the Jesuits' claims of linguistic proficiency should not always be taken at face value, del Valle incorrectly states that "este proceso de aprendizaje es eludido 
en la escritura de los misioneros" (77). In fact, the missionary's struggle with Amerindian languages is a leitmotif of Jesuit narrative in both the hagiographic and scientific modes, as well as in missionaries' personal correspondence; while the Jesuits' mastery of Amerindian languages was frequently celebrated, the cost of this mastery in self-abnegating and meticulous study is also well-documented. As revealed by Acosta's De procuranda, mastery of Amerindian languages as a mastery of the self, a kind of linguistic heroism, was already an essential part of the Jesuits' missionary ideal well before the eighteenth century. For every Francisco Hermano Glandorff, who was said to speak "el bárbaro idioma Tarahumar [...] como si le hubiera sido nativo" there was a Father Helen who was forced to submit to the "rudo y penoso magisterio de un Indio" (Braun 7). Even Juan Eusebio Kino (16451711), who was a celebrated linguist and authored numerous grammars and vocabularies of the Amerindian languages of Sonora, was said to have learned these languages only after "venciendo el enojoso tedio" of apprenticeship (Burriel 2: 88) ${ }^{4}$.

The Jesuits' struggles with the languages of the missionary frontier are perhaps best understood in comparison with their mastery of other Amerindian languages in New Spain with which Europeans had experienced a prolonged exposure by the eighteenth century. Juan Bautista Zappa (1651-1694) and Juan de Ugarte, for example, were said to be accomplished Nahuatlistas before their missionary work among other linguistic groups. In another case of the Jesuits either intentionally or inadvertently imitating Amerindian cultures, Miguel Venegas claims that Zappa was given the title "temachtiani," or doctor, by his Nahuatl-speaking catechumens due to his mastery of their language in his sermons (Vida y virtudes 115v). Juan de Ugarte, who taught in the Jesuit colleges of the colonial center before his missionary work in California, insisted that his confrères perfect their fluency in the "Idioma Mexicano," or Nahuatl, and to such end organized study groups:

Proovió en su colegio el Padre Juan con singular esmero el estudio del Idioma Mexicano, a el qual era el primero que se aplicaba, y para conseguir que sus súbditos lo aprendiesen y usasen con la mayor perfección, las tardes desocupadas de otros ministerios, juntaba a los Padres en su aposento, y juntos hacían ejercicio del Idioma, construyendo, preguntando, y respondiendo los puntos más difíciles del. Acabado este ejercicio, el Padre Rector (en todas sus acciones magnánimo, y caballero) daba a sus Súbditos un buen refresco, que tenía de antemano prevenido (Villavicencio 42-43).

Ugarte's diligence in the study of Nahuatl is presented here as an academic exercise undertaken among peers, that is, fellow Jesuits who share a similar cultural background;

\footnotetext{
${ }^{4}$ The reality behind the Jesuits' sometimes exaggerated claims of linguistic mastery was not lost on their contemporaries. Although not an entirely reliable source with regard to the merits and faults of the Jesuits, Mathias de Anglés y Gortari's 1731 "Informe" delivered to the Holy Office of Lima in defense of José de Antequera's defiance of the Crown and the Society Jesus in Paraguay offers some insight into the reality behind the order's ideal of linguistic heroism. In criticizing the Jesuits' policy of sending foreign-born missionaries of advanced age (most not even Spanish) to Paraguay, a practice also observed in New Spain, Anglés y Gortari claims that many not only never mastered the Guaraní language but even had difficulty speaking Castilian (47-48). Despite the author's bias, the reasons he adduces are convincing: the Jesuit missionaries arrived at too advanced an age (30 to 40 years old) to acheive fluency, and Guaraní is particularly difficult to master if not spoken from childhood. Moreover, Anglés y Gortari deflates the claims that the Jesuits had gained fluency from studying their "Arte y Diccionario," arguing that no language, and even more so Guaraní, could be learned by studying a text without practical application.
} 
and though mastery of the language was useful to missionaries such as Zappa, the language also enjoyed a certain prestige among the contemporary Criollo intellectual elite, as evidenced in Carlos de Sigüenza y Góngora's life-long study and mastery of the language (Irving 92). Of course, native speakers are conspicuously absence from Ugarte's genteel study sessions, and they are only present as a captive audience to Zappa's supposed command of their language. Unlike the amicable dialectic in Father Juan's quarters in Mexico City, however, the experience of reproducing the Amerindian languages of the missionary frontier challenged the authority of the missionary and his culture.

In the same text that celebrated Ugarte's application to the study of Nahuatl, his hagiographer likewise employs the aforementioned leitmotif of humbling submission to Amerindian instruction in its description of the Jesuit's first attempts at learning the languages of the Californios: "Así se ajustó al consejo de San Pablo, de hacerse ignorante para ser sabio verdaderamente, aprendiendo de los mismos a quienes iba a enseñar la sabiduría del cielo" (Villavicencio 57). Ugarte, "educado con regalo en el siglo lograba en México dentro y fuera de la religión los mayores aplausos" (Burriel 2: 115), was forced to submit to the instruction of the ignorant, yet this act was prefigured in the protoApostle's First Letter to the Corinthians. Somewhat paradoxically, St. Paul's admonition against worldly wisdom, "Do not deceive yourselves. If you think that you are wise in this age, you should become fools so that you may become wise," authorized Jesuit mastery over their Amerindian catechumens, for in willingly renouncing recognition for their years of arduous study they would reaffirm their superiority over the ignorant (1 Cor. 3.18). The fact that this mastery was not self-evident to the Californios is demonstrated by an anecdote involving the same Father Ugarte. In the Noticia de la California, Burriel recounts that Ugarte, who had assiduously studied the language of the Guaycuras, was vexed by the laughter that his first sermons produced among his catechumens, and in the middle of a lesson stood up and began to savagely strike the pupil who seemed to show the most blatant disrespect for his teachings (2: 116). Only later did Ugarte discover that the Guaycuras were laughing at his poor pronunciation of their language and his inappropriate use of certain words and phrases that his tutors had mischievously taught him in order to have a laugh at his expense. After this incident Ugarte was wary of his informants and "procuró poner más cuidado para instruirse en uno, y otro [vocabulario y pronunciación] tomando por maestros a los niños, haviendo averiguado, que los adultos, sobre resistirse, le engañaban, para burlarse después" (2: 117).

Though this episode is frequently cited in studies of the Jesuit missions of Lower California, the fact that the Guaycuras not only ridiculed the linguistic errors but also took an active role in subverting the tutelage of the missionary ("sobre resistirse, le engañaban, para burlarse después") is overlooked; it would seem that the Californios were capable of inverting the trope of mimicry in order to parody their schoolmasters. ${ }^{5}$ Even armed with this newfound circumspection, Ugarte experienced a protracted and onerous apprenticeship due to, in the words of Burriel, the "rudeza brutal de aquellos infelices" (2: 117). Instead of demonstrating that the Californios were capable of subverting the process of acculturation, or even acculturating the Jesuits, Burriel takes this anecdote as further

\footnotetext{
${ }^{5}$ See del Valle (78)
} 
evidence of their brutishness. Burriel's text reasserts the violence that established the order and direction of colonization, a violence which ultimately guaranteed the continued performance of the Jesuit ascetic ideal on the mission frontier.

This linguistic heroism was not diminished in the Jesuit natural histories that, while based on the edifying letters and missionary hagiographies, were written in Europe and focused on those aspects of the missionary enterprise that would appeal to a secular reading public. In these works the Jesuits' linguistic mastery increasingly grants authority to the missionary as a meticulous observer and ethnographer, but it is no less portrayed as a result of the missionary's self-mastery. The following passage from Burriel's Notice de la California, which emphasized the ethnographic, geographic and natural descriptions of the Criollo Jesuit Miguel Venegas' Empressas apostólicas, reiterates all of the details of this leitmotif:

El padre Salvatierra se dedicó desde luego a la enseńanza de los indios, y a aprender la Lengua, señalando para esto horas, en que los Indios concurrían a repetir las Oraciones, y Doctrina, que les leía por los Papeles de Copart: y el padre los oía hablar después, con la pluma en la mano, para notar sus voces, hablando el Padre, y enmendandole los Indios los yerros de los vocablos, o de la pronunciación. Enseñaba a los niños el Castellano, valiéndose de varias industrias: sufría las burlas, con que ellos, y los adultos mofaban de los yerros, que cometía, al pronunciar su lengua: burla, que saben hacer con donayre, y socarronada [...] Menudencias parecerán estas acaso, en que no debieramos detenernos. Mas yo ruego a quien leyere, que para darlas el valor que merecen, las pese en las balanzas del Santuario, reflexionando, qué espectáculo tan agradable sería a los ojos de Dios un hombre que pudiendo haver hecho gran fortuna, y aun vivido con estimación, y quietud dentro de la Religión, que había escogido, se desterró voluntariamente de su Patria, y Parientes, por passar a la América [...] por vivir sólo entre Bárbaros, con tantas incomodidades, y peligros de muerte (2: 20).

Father Salvatierra is portrayed as patiently suffering not only the tutelage of his catechumens but also their ridicule ("que saben hacer con donayre") in his onerous apprenticeship in their language. Furthermore, Salvatierra's apostolic merit is magnified by his choice of voluntary exile among the "bárbaros" of the mission frontier in place of the fame and luxury that he could have obtained in an urban college, a detail that, according to Burriel, must be measured against the lives of the saints.

In his Historia de la Antigua o Baja California (1789), the Novo-Hispanic Jesuit Francisco Javier Clavijero, writing from exile in Bologna, emphasizes the task of learning the Californios' language as a means to establishing the Catholic and Spanish hegemony in the peninsula, which he claims was only possible thanks to the efforts of his brethren. With regard to Pedro de Ugarte, Clavijero writes,

Después que con semejante industria aprendió el dialecto de aquellos indios, se dedicó a catequizarlos, acariciándolos y regalándolos para obligarlos a asistir al catecismo, y valiéndose también de los niños para instruirlos; hasta que con un trabajo indecible y con una paciencia y una constancia heroicas, consiguió reducir a vida social y cristiana no sólo a los de Liguig, sino a todas las tribus vecinas y a muchos salvajes dispersos en los montes (125-26). 
While Clavijero emphasizes Ugarte's "industria” as a means to establishing a secular regime on the peninsula, he nevertheless mentions the fact that the missionary, like Salvatierra, had turned his back on the nobility and fortune of his family, another central trope of the Jesuits' ascetic ideal disseminated in the orders vast corpus of edifying letters, hagiographies and chronicles (125). Clavijero furthermore places emphasis on Ugarte's "heroic" display of the cardinal virtues of patience and perseverance, which were cornerstones of the Jesuit hagiographic works, or Vidas y virtudes, published in New Spain throughout the eighteenth century until the expulsion of the order in $1767 .{ }^{6}$ In one of the most noteworthy examples of this continuous and painstaking study of Amerindian languages, Clavijero writes that Clemente Guillén, who had arrived in the peninsula in 1714 and remained in Loreto even after his retirement from missionary work thirty years later,

[...] más aún allí continuó trabajando cuanto le fue posible, y dio un raro ejemplo de celo, porque habiendo llegado a la misión, de tierra muy remota, una india anciana cuya lengua no entendían los misioneros, él a la edad de setenta años se puso a aprenderla con el solo fin de doctrinar aquella mujer, y en este heroico ejercicio de caridad le sobrevino la muerte en 1748 (201).

Even these works prepared for a secular European reading public portray the Jesuits' linguistic heroism as a humbling, painstaking and prolonged exercise of self-discipline, which formed the basis of the order's ascetic ideal as well as the foundation of ChristianCastilian hegemony by providing an ethical orientation of conduct that justified the colonial order even in the context of radical inequalities.

The experience of Francisco María Piccolo (1654-1729), the missionary who accompanied Salvatierra on his first expedition to Lower California after years of experience in the missions of the northwest frontier of New Spain, reveals the personal challenges faced by missionaries in submitting to the instruction of Amerindians as well as the transformation of this experience through the discourse of Jesuit historiography. While there were Jesuits who doubtlessly possessed a gift for languages and achieved a high degree of fluency in Amerindian languages, Piccolo's history reveals the tension between the ascetic ideal of linguistic mastery and the reality of the missionary's experience on the frontier. Even in Juan Antonio Balthasar's idealized "carta edificante" on the life of Piccolo this tension is evident. Balthassar writes that Piccolo was beset by despair at his isolation

\footnotetext{
${ }^{6}$ José Toribio Medina's La imprenta en México, the most exhaustive bibliography of works published in New Spain during the colonial period, registers at least 41 works of Jesuit hagiography, commonly titled Vidas y virtudes, published during this period. These include very brief Cartas edificantes on Jesuit subjects that were prepared for press as well as a two volume menology on the Society's coadjutors penned by Juan Antonio de Oviedo. Some of the works are translations of Jesuit hagiographies written in other languages, such as José María Galluci's Vida del Venerable Padre Antonio Baldinucci misionero apostólico de la Compañia de Jesús (translated from Italian to Spanish), and works on non-Jesuit subjects such as Juan José Moreno's Fragmentos de la vida, y virtudes del V. Illmo y Rmo. Sr. Dr. Vasco de Quiroga. These works also include an edition of Plácido Spirembergo's Carta edificante on Juan Antonio Cantova, a Jesuit who was killed on the mission frontier of the Philippines. Notwithstanding a handful of exceptions, including Antonio de Paredes work on the Otomí nun Salvadora de los Santos studied below, most of the texts focus on the lives of Jesuits who performed missionary work in New Spain during the eighteenth century. Of course, Medina's bibliography does not include manuscript works such as Miguel Venegas' Empressas apostólicas and Vida y virtudes del V.P. Juan Baptista Zappa.
} 
on the frontier in his first mission among the Tarahumara, a solitude that was deepened by his inability to communicate with his would-be catechumens. In Balthasar's words,

Parece, que su grande, y especial devota la gloriosa Virgen, y prodigiosa Anachoreta Santa Rosalía, quiso asemejarlo a sí; pues sabemos, que la Santa a los principios de su varonil, y heroyca resolución de vivir sepultada en una cueva, padeció notable tedio, y horror a la soledad. No era el verse solo el principal motivo de la tristeza, que el P. padecía, lo que principalmente lo desconsolaba era, que ni entendía a los Indios, ni era entendido de ellos; y assí la mayor parte del día la passaba llorando amargamente; probando Dios assí a su Siervo, con tenerlo en tan grande desolación (31).

In another ironic reversal of roles in the mimetic "space between," Piccolo's biographer compares his inability to communicate with his catechumens to the twelfth-century Sicilian anchorite Saint Rosalia's solitary burial in a cave, for which Piccolo bitterly lamented his fate. In this case, the Jesuit missionary was reduced to, as in Acosta's formulation, a "bárbaro entre los bárbaros" who was unable to communicate the message he was sent to convey. In recognition of this speechless solitude, Picolo would later choose the name Santa Rosalía de Mulegé for one of the first mission settlements in Lower California. The advice supposedly given to the despairing Piccolo by a fellow missionary, "reze la doctrina por el papel, que de ella hay," furthermore reveals just how improvised and precarious communication could be on the missionary frontier (31). Piccolo's only means of communication was a rudimentary phonetic translation of the "doctrina" (Credo, Pater Noster, and Ave Maria), frequently used by missionaries on the frontier, from which he parroted the language of his catechumens.

Despite these revealing details from Piccolo's biography, the missionary's own Informe del Estado de la nueva Cristiandad de la California (1703) presents a more idealized version of the linguistic exchange, although he stresses the Californios' active participation in a dialectic with the Jesuits. Despite the Californios' reasoned objections to the missionaries' doctrine, Piccolo writes that they eventually ceded to the force of reason:

Su genio es muy vivo y despierto, y lo muestran, entre otras cosas, en mofar mucho cualquiera barbarismo en su lengua, como al principio lo hizieron con nosotros al predicarles. Después de estar domesticados, se llegan a corregirnos, despues de predicar qualquier desliz en su lengua. En predicandoles algunos mysterios contrarios à sus antiguos errores, acabado el Sermon, se llegan à el Padre, le reconvienen de lo que dixo, y le arguyen y discurren en favor de su error con bastante aparencia; y à la fuerça de la razon, se sosiegan con toda docilidad (65-6).

Notwithstanding the Californios' ridicule of the Jesuits' barbarisms, Piccolo notes the ease with which his confrères learned the language (52). The fact that Piccolo's Informe was intended to solicit financial support for the Jesuit enterprise from the Viceroy of New Spain, the Count of Moctezuma, was likely the reason behind his optimistic portrayal of the order's efforts to establish permanent missions on the peninsula. In more unguarded correspondence with his brethren, however, Piccolo revealed that communication was at best precarious in the first years of the Jesuit enterprise in Lower California. 
In a letter written to Salvatierra from the mission at Santa Rosalía de Mulegé in 1709, Piccolo describes his efforts at making inroads among the Cochimíes, whose language was unfamiliar to the missionaries. Piccolo suggests that he was able to communicate his purpose to the Cochimíes, yet he affirms that the written speech he had prepared was of little use and he was forced to appeal to a higher power: "Les prediqué y les dije el fin de mi llegada a sus tierras. Tenía escrita la primera plática para esta entrada pues hablan muy diferentes de los Laimones y deseaba hablar al su modo de ellos. Finalmente dije lo que Dios me sugerió y quedaron muy gustosos [...]"(Letter to Juan María Salvatierra). It is impossible to know just how successful Piccolo's divinely suggested discourse was in convincing his new catechumens of their errors, but an overview of his documented experiences on the Jesuit missionary frontier casts doubt upon his assertions. On the mission frontier the Jesuits were placed in a situation in which their hard-won social prestige and authority was of little or no use in achieving their goals; not even the technology of writing, which the Jesuits had converted into a powerful tool for maintaining corporate discipline and promoting the order through the circulation of edifying letters and histories, could aid Piccolo in the unstable dialogic exchange with the Californios. Writing was, however, the means of establishing the Jesuits' authority ex post facto through hagiography and natural history, whereby this loss of prestige -a simple fact of the contact zone- was transfigured into an ascetic submission of the will.

Despite their principal function of producing the categories (e.g. "bárbaro") that defined geography of the northern reaches of New Spain in relation to the social spaces of the colonial center and metropole, these narratives also often reveal the inconsistencies of these categories in accounting for the complex cultural exchanges between missionaries and Amerindians on the mission frontier. The Noticia de la California, for example, portrays a kind of pedagogical war between the Jesuit newcomers and the "guamas," or shamans, of Loreto, who were said to run their own clandestine schools where they attempted to pass their culture on to the same children that were the target of the Jesuits' campaigns. Whether characterized as satanic agents or cynical charlatans, the guamas, those responsible for the preservation and transmission of local knowledge in their communities, were seen as competitors for ideological supremacy within Lower California and thus were a principal target of both the spiritual and temporal conquest of the peninsula. The Jesuit author labels the guamas' teachings as "necedades inutiles," which they were forced to teach out of view of the missionaries: "Retiraban para esto a los niños a algunas cuevas, o parajes apartados de los bosques, y allí les enseñaban a formar ciertas figuras en unas Tablas" (1: 111-112). Although Jesuit histories frequently characterize the Californios as lacking any technique resembling writing, here the shamans are described as preserving arcane symbols on "tablas" which their students were taught to reproduce. Furthermore, the pedagogical technique employed by the shamans is compared to that of the Jesuits: "aprendidas aquellas [figuras], les enseñaban otras al modo, que se hace en la Escuelas, para enseñar a escribir a los niños" (1:112). In the representation of the rival pedagogical regime of the guamas, Jesuit narrative not only reveals the resistance to acculturation, but also demonstrates how the order's historiography often dissolves into incoherency and paradox when attempting to represent the fundamental differences between colonizers and colonized through the discourse of magisterium and the Western tradition of asceticism. The guamas 
are associated with classic spaces of barbarism in the West -the cave and the forest- yet in the same passage these spaces become the scene for the development of writing and the institution of schooling beyond the influence of Europeans. The Californios are first subject to an absolute dichotomy of nature and culture (or barbarism and civilization) but as they resist the regime based on this dichotomy they are then portrayed as possessing the tools of civilization if only to misuse them in a perverse mimicry of the colonizers' culture.

It is tempting to read this episode as a case of shamanic mimesis similar to those of the Cuna culture examined by Michael Taussig. Burriel's description of the Californian guamas as imitating the institutions and gestures of the colonial agents of acculturation is uncannily similar to Taussig's descriptions of a Cuna healer donning Western garb in a process of imitating the other in order to become the other in a ceremony that releases the magical power from objects fashioned after Western models (188-192). Just as in the Cuna healer's ceremony, the Western ethnographer (or Jesuit historian) likewise represents the colonial other through textual representation in order to steal away his power. This representation (or imitation) of the Amerindian (imperfectly or perversely) imitating the colonizer's mastery is a frequently repeated trope of colonial discourse that neutralizes the threat of a rival pedagogical regime. Perhaps more than an empirical example of shamanic mimesis, this anecdote displays the centrality of the trope of mimicry, which, as Homi Bhabha suggests, reveals both the narcissism of the colonial agent (i.e. wishing to reproduce himself in the other) and his paranoia (i.e. fearing that the other may reproduce him too perfectly) (132). Thus, colonial discourse presents the colonized subject's efforts to imitate the colonizer's culture, which would paradoxically signal the success of the Jesuits' enterprise, as a parodic aping or uncanny hybrid, just as Burriel portrays the guamas as attempting to reproduce writing and the classroom in the barbaric setting par excellence for the West (the cave) in order to undermine the missionaries' evangelical campaign.

Whether empirical fact or discursive strategy, rival pedagogues were not the only challenge faced in the establishment of the Jesuits' mastery on the mission frontier. Jesuit historiography provides glimpses of the subversion of the order that the missionaries attempted to impose in the absence of institutional supports. This subversion was not limited to rival pedagogical regimes, and in some cases Jesuit historians portray their confrères as in danger of being acculturated by their catechumens. In one example, Juan de Ugarte, the same missionary who reacted violently to the ridicule of the Guaycuras, was forced to adopt the hunter-gatherer subsistence of his catechumens after the Jesuits' failed attempts to establish a sustainable agricultural economy in the missions (Burriel 121). And in a case of cross-dressing that must have bemused the Californios, Spanish soldiers used the headdresses of Californio women to tie up their hair (Burriel 84). These examples demonstrate the inadequacy of the missionaries' culture for survival in the peninsula as well as the ambivalence of mimesis in the contact zone. Indeed, one of the recurrent themes in Jesuit testimonies and histories is the hunger endured by the apostles and their catechumens due to the interruption of the Californios' forms of subsistence and the delay of food and supplies arriving from Sonora. Despite this occasional subversion, however, the asymmetrical relation of violent force ensured that the cultures of Lower California would ultimately face extinction. In approaching these paradoxes of the missionary frontier, Jesuit historiography invoked writing itself as a tool that would confirm the universal and unidirectional extension of Western culture on the colonial periphery. 
There was one form of universal communication that seemed to be successful in reestablishing the direction of acculturation on the mission frontier: coercive violence. The Jesuit historiography of Lower California emphasizes that the order's enterprise in the peninsula was a form of "spiritual conquest" as opposed to the unsuccessful attempts, beginning with Hernán Cortés aborted venture in 1534, at armed conquest of the peninsula and its inhabitants. Francisco Zevallos' "Carta edificante" on the life of Fernando Consag, who served as a missionary on the northern extremes of the peninsula, expresses this ideal of acculturation and colonization, "Ganar así los corazones de los hombres, es un género de Conquistas, que hace un misionero desarmado, y no puede hacer todo el estruendo, y terror de las armas. Tanto más poderosas son las armas del zelo, mansedumbre, y caridad cristiana, que son las con que se fundó, y se propaga el Imperio de Jesu-Cristo" (13). This ideal of spiritual conquest is derived from the basic concept of Christian conversion, or metanoia, brought about through the example of charity and sacrifice, as practiced by Jesus Christ in the Gospels. Notwithstanding this oft-heralded concept of spiritual conquest, some Jesuit correspondence and narrative suggests that Jesuit reducción frequently made use of coercive means. ${ }^{7}$ In a letter to Juan de Ugarte sent from Lower California in 1697, Salvatierra describes the first tense days upon the arrival of the Jesuits and their entourage of soldiers and settlers. ${ }^{8}$ Communication was hindered not only by a mutual lack of linguistic knowledge but also by the Californios' previous experiences of exploitation by rogue expeditions seeking pearls and mineral wealth in the peninsula. Salvatierra recounts the days leading up to a pitched battle with Californios,

Antes de que llegase el día de la pelea se hizo todo lo posible para que reconociesen la fuerza de nuestras armas, así en algunos buenos tiros tirando a los patos y animales: y la noche misma antecedente mató un soldado que estaba de guardia a un coyote muy gordo, que ellos pidieron para comerselo, y en nuestra presencia lo [comieron] como comida de grande sabor. También se puso un blanco de una tabla de grande distancia, y tirando todos por mostrar que yo también sabía tiré, y fue uno de los mejores tiros. Tiraron también ellos con sus flechas, y después del exercicio al traerse la tabla vieron los agujeros de las balas, y se cotejó con el rasguño de las flechas y quedaron admirados de ver la diferencia de los tiros de unas y otras armas $[\ldots](13 \mathrm{v})$.

In this letter, one of the first missives sent from Lower California, Salvatierra reports that his first act of successful communication with his future catechumens was a performance of the Jesuits' ability and willingness to use lethal force. Contrary to Piccolo's assertion,

\footnotetext{
${ }^{7}$ Del Río describes the Jesuit enterprise as a "conquista misionero-militar" in which "Aun en los casos en que, por razones tácticas, se prescindía del uso de las armas, la violencia permanecía latente puesto que en cualquier momento podía activarse el aparato militar para ofender, para repeler agresiones, para reprimir o simplemente para amedrentar a los nativos y prevenir de ese modo situaciones de conflicto" (94).

${ }^{8}$ Despite the fact that Jesuit historiography often promotes the impression that the Jesuits were alone among the Californios, it is important to remember that they were accompanied by a significant entourage of soldiers and settlers from New Spain. A "Memorial" with a written in 1700 by Salvatierra reveals that even in the early years of reducción the Jesuits were far from alone. The Jesuit's "censo de pobladores" includes "sesenta almas de cristianos de la Nueva España entre padres espańoles y gente de familias, treinta hombres de armas espańoles incluyendo capitán y alférez, dos españoles ventureros sin sueldo, diez indios amigos de la Nueva Espańa armados de arco y flechas, dos mulatos sirvientes, cinco filipinos pampangos y el resto mugeres y nińos con caserías de adobes y otras estacadas y tierra todas en orden y bien techados y rodeado todo de un fuerte recinto de estacada y tierra para resistir a las armas de indios con una lancha varada en la playa a que pueden servir los filipinos en casa de grande urgencia [...]”.
} 
this would seem to demonstrate that the Californios first ceded to the reason of force before the Jesuits had the chance to demonstrate the force of their reason. As Burriel asserts, this was a deliberate strategy: "aquellos bárbaros se deben sujetar primero con el terror, y miedo, quando resisten; porque de este modo creen después fácilmente, que nace de amor cualquier beneficio que se le hace después" (410).

The violence wrought in the establishment of the Jesuit mission regime in Lower California assured the success of the acculturation of the inhabitants of the peninsula at the same time that it represented the failure of the Jesuits' ideal of "spiritual conquest." The Jesuits' mission furthermore failed insofar as it aimed to create Christian and political subjects and not exterminate them. ${ }^{9}$ The process of acculturation combined with the devastation wrought by the diseases and violent reprisals of Europeans assured that Clavijero could confidently speak of many of the indigenous cultures of the peninsula in the imperfect:

La lengua pericú ya no existe, y los pocos individuos que han quedado de aquella desgraciada nación hablan hoy la española. La guaicura tenía tantos dialectos diversos cuantas eran las ramas de la nación que la hablaba, a saber: guaicuras propiamente dichos, aripas, uchitas, coras e indios de Conchó, llamados después lauretanos por el pueblo de Loreto que se fundó cerca de ellos. La rama de los uchitas y la de los coras se extinguieron; los lauretanos abandonaron su lengua por la española, y los otros restos de aquella nación conservan la que hablaban antiguamente (50).

One is surprised to read of the widespread death and suffering of the Californios in a history that is ostensibly meant to portray the success of peaceful conquest, yet the hecatomb of the peninsular Amerindians was a fact that the historians of the enterprise could not easily gloss over. Venegas, Burriel and Clavijero seem to have tried to balance this fact by emphasizing the physical suffering and privation experienced by the Jesuits, which culminated with the martyrdom of Fathers Carranco and Tamaral in the Pericú rebelion of 1734 . Breaking with the overall somber tone of the Noticia, Burriel vividly recounts the torture and dismemberment of Carranco and Tamaral at the hands of their catechumens, attributing the uprising to an irrational rejection of the benign process of "spiritual conquest" instead of the Californios' reasonable association of their suffering with the presence of the outsiders (2: 469-70).

Writing, then, was doubly significant on the missionary frontier: on the one hand, its supposed absence among the Amerindian inhabitants of Lower California provided evidence of the nearly unbridgeable chasm between the missionary and catechumen, thereby increasing the apostolic merit of the Jesuit who, following the divine mandate of magisterium, set forth to draw new subjects into the fold of Christianity and Western civilization; on the other hand, writing was the medium with which the Jesuits justified their enterprise and converted the data of the frontier into socially significant facta

\footnotetext{
${ }^{9}$ Historians have estimated that the Peninsula was inhabitated by between 40,000 and 50,000 Amerindians at the beginning of the eighteenth century. By the end of the Jesuit experiment in Lower California, the population is estimated to have dropped to around 7,000. According to Ignacio del Río, the principal causes of this steep demographic decline were disease, violent reprisals by viceroyal officials, the separation of women and children from their families, and the interruption of the hunter-gatherer subsistence of the Californios (Altable Fernández and del Río 66-67).
} 
through the repetition of an ascetic ideal. ${ }^{10}$ It is important not to lose sight of the fact that this ascetic ideal, whether realized through the missionary's vocation or through the textual representation of his life, was in both cases a performance, even though it was legitimated and disseminated by powerful institutional supports. Facing the centrifugal forces of the frontier contact zone, as witnessed in the Californios' laughter during the Jesuits' language lessons, the missionary and his hagiographer enact a scene of ascetic self-denial based on models taken from the Greco-Roman and Christian tradition. This performance is consummated when the Jesuit subject ultimately renounces his life and will to the representation of his life within the tradition of sacred texts, becoming a model of conduct for readers both within and outside of the order. The Jesuits' prolific hagiographic and historiographic production united the Christian concept of magisterium with the performance of the ascetic ideal in order to reproduce social relations based on obedience, perseverance and the patient suffering of indignities, yet these works also reveal that this performance was contingent on the pervasive violence of the colonial mission frontier. As read against backdrop of magisterium and the ascetic ideal, the scenes of Jesuit submission to the "rudo y penoso magisterio de un indio" likewise reveal the complex play of mimesis at the edges of Western civilization.

\section{REFERENCES}

Acosta, José de. De procuranda indorum salute. 2 Volúmenes. Madrid: Editorial Luciano Pereña. Corpus Hispanorum de Pace 23-24. Madrid: Consejo Superior de Investigaciones Científicas, 1987.

Altable Fernández, María Eugenia y Del Río, Ignacio. Breve Historia de Baja California Sur. México, D.F.: Fondo de Cultura Económica, 2000.

Anglés de Gortari, Mathias. Los jesuitas en Paraguay: Copia del informe que hizo el general Mathias de Anglés y Gortari sobre los puntos que han sido causa de las discordias sucedidas en la ciudad de la Asunción, de la provincia del Paraguay, y motivaron la persecución de Josef de Antequera, de parte de los Regulares de la Compañia. Asunción del Paraguary: A. de Uribe, 1896.

Balthassar, Juan Antonio. Carta del P. Provincial Juan Antonio Balthassar, en que da noticia de la exemplar vida, religiosas virtudes, y apostólicos trabajos del ferveroso Missionero el Venerable P. Francisco Maria Picolo. México: n. p., 1752.

\footnotetext{
${ }^{10}$ Here I am employing the American philosopher John Searle's useful distinction from The Construction of Social Reality. As a performative, the reproduction of the concept of the mission frontier is what Searle calls a "status-function," or an utterance that realizes the social order that it names. For Searle, every community operates within a "collective intentionality" that produces and perpetuates an institutional reality through performative utterances. Institutional facts, or factum, consist of functions that are assigned to nature beyond its giveness, or datum, and to relations of power established through institutions (41). Whether defined as a wilderness traversed by apostles in the eighteenth century or as a border between imagined communities in the twenty-first century, the concept of "frontier" is perhaps the best example of the application of an institutional reality, or factum, to nature and human communities.
} 
Bhabha, Homi. "Of Mimicry and Man: The Ambivalence of Colonial Discourse." October. 28 (Spring, 1984): 125-133.

Braun, Bartholome. Carta del P. Bartholome Braun visitador de la Provincia Tarahumara a los PP. Superiores de esta provincia de Nueva España sobre la apostólica vida, virtudes, y santa muerte del P. Francisco Hermano Glandorff. México: Impressa en el Real, y mas antiguo Colegio de San Ildefonso, 1764.

Burriel, Andrés Marcos y Venegas, Miguel. Noticia de la California, y de su Conquista temporal, y espiritual, hasta el tiempo presente. Sacada de la historia manuscrita, formada en México año de 1739. por el Padre Miguèl venegas, de la Compañia de Jesús; $y$ de otras Noticias, y Relaciones antiguas y modernas. Madrid: Imprenta de la Viuda de Manuel Fernández, 1757.

Clavijero, Franisco Xavier. Historia de la Antigua o Baja California. Ed. Miguel LeónPortilla. México, D.F.: Porrúa, 1970.

Cuevas, Mariano. Historia de la Iglesia en México. Volumen 1. Tlalpam, D.F., México: Imprenta del Asilo Patricio Sanz, 1921.

Del Río, Ignacio. Conquista y acculturación en la California jesuitica, 1697-1768. Serie Historia Novohispana 32. México, D.F.: Universidad Nacional Autónoma de México, 1998.

Del Valle, Ivonne. Escribiendo desde los márgenes. Colonialismo y Jesuitas en el siglo XVIII. México, D.F.: Siglo XXI Editores, 2009.

Flood, Gavin. The Ascetic Self: Subjectivity, Memory and Tradition. Cambridge: Cambridge UP, 2004.

Galt Harpham, Geoffrey. The Ascetic Imperative in Culture and Criticism. Chicago: University of Chicago Press, 1993.

Habermas, Jürgen. The Theory of Communicative Action. Trans. Thomas McCarthy. 2 vols. Boston: Beacon Press, 1984.

Hadot, Pierre. Philosophy as a Way of Life. Trans. Michael Chase. Malden, MA: Blackwell, 1995.

Irving, Leonard. Don Carlos Sigüenza y Góngora, a Mexican Savant of the Seventeenth Century. Berkeley: University of California Press, 1929.

Leti, Juan Santiago. Practica utilissima de los diez viernes a honor de S. Ignacio de Loyola, Patriarcha de la Compañia de Jesús. Trans. Juan Francisco Lopez. México: En la Imprenta del Nuevo Rezado de Dońa Maria de Rivera, en Empedrillo, 1749. 
Medina, José Toribio. La imprenta en México, 1539-1821. 8 volúmenes. Santiago de Chile: Impreso en casa del Autor, 1907-1912.

Nietzsche, Friedrich. Human, All Too Human: A Book for Free Spirits. Trans. Marion Faber and Stephan Lehmann. Lincoln: University of Nebraska Press, 1996.

. On the Genealogy of Morals. Trans. Walter Kaufman and R.J. Hollingdale. New York: Random House, 1989.

Ormea, Francisco Amadeo de. Compendio de la vida de nuestro Padre y Patriarca San Phelipe Neri. Que en forma de meditación para el aparejo espiritual de la Fiesta del Santo hizo en lengua toscana el P. Francisco Amadeo de Ormea de la Congregación de Turin. Trad. Antonio Díaz de Godoy. México: Herederos de la Viuda de Miguel de Ribera Calderón, 1714.

Piccolo, Francisco María de. Informe del Estado de la Nueva Cristiandad de California, 1702, y otros documento. Ed. Ernest J. Burrus. Madrid: Ediciones José Porrua Turanzas, 1962.

. Letter to Juan María Salvatierra. June 24, 1709. Huntington Lib., Pasadena, CA. HM 4097.

Polzer, Charles W. "Kino: On People and Places."In Christopher Chapple (Ed.), The Jesuit Tradition in Education and Missions: A 450-year Perspective. Scranton: University of Scranton Press; London: Associated University Presses, (1993): 230-241.

Pratt, Mary Louise. Imperial Eyes: Travel Writing and Transculturation. New York: Routledge, 1992.

Salvatierra, Juan María. Letter to Juan de Ugarte. November 27, 1697. Real Academia de la Historia. Colección Boturini. Tomo 1, folios 303-322. Copy held at the Huntington Library, Pasadena, CA. CA.

Searle, John. The Construction of Social Reality. New York: Free Press, 1995.

Spicer, Edward. Cycles of Conquest: The Impact of Spain, Mexico and the United States on the Indians of the Southwest, 1533-1960. Tucson, AZ: University of Arizona Press, 1992.

Taussig, Michael. Mimesis and Alterity: A Particular History of the Senses. New York: Routledge, 1993. 
Venegas, Miguel. Empressas apostólicas de los padres misioneros de la Compañía de Jesús, de la Provincia de Nueva-España obradas en la conquista de Californias debida y consagradas al patrocinio de Maria Santissima, Conquistadora de nuevas gentes en su sagrada imagen de Loreto. La Paz, Baja California Sur, México: Universidad Autónoma de Baja California Sur, 1979. Vol. 4 of Obras californianas de Padre Miguel Venegas, S.J. Ed. Michael Mathes. 4 volúmenes. 1979.

Vida y virtudes del V.P. Juan Baptista Zappa (c. 1729). Ms. HM 522. Huntington Library, Pasadena, CA.

Villacañas, José Luis. ¿Qué imperio? Un ensayo polémico sobre Carlos Vy la España imperial. Madrid: Almuzara, 2008.

Villavicencio, Juan Joseph de. Vida y virtudes de el venerable, y apostólico padre Juan de Ugarte de la Compañia de Jesús, Misionero de las Islas Californias, y uno de sus primeros conquistadores. México: La Imprenta Real, y más Antiguo Colegio de San Ildefonso, 1752.

Weber, Max. "The Social Psychology of the World Religions." From Max Weber: Essays in Sociology. Trans. H.H. Gerth and C Wright Mills. New York: Oxford UP, 1946. 267-301.

Wimbush, Vincent l. and Richard Valantasis, eds. Asceticism. New York: Oxford UP, 1998.

Zevallos, Francisco. Carta del Padre Provincial Francisco Zevallos sobre la apostólica vida y virtudes del P. Fernando Konsag, insigne misionero de la California. México: Real, y más Antiguo Colegio de San Ildefonso, 1764. 